\title{
REAKSI PASAR ATAS PENERBITAN SUKÛK \\ (STUDI PADA EMITEN SAHAM PENERBIT SUKÛK PERIODE 2008-2012)
}

\author{
Vita Fatimatuzzahra \\ Mahasiswa Program Studi S-1 Ekonomi Islam - Fakultas Ekonomi dan Bisnis - Universitas \\ Airlangga \\ Leo Herlambang \\ Departemen Ekonomi Syariah - Fakultas Ekonomi dan Bisnis - Universitas Airlangga \\ Email: leo.herlambang@gmail.com
}

\begin{abstract}
Issuance of Sukûk's corporation, it can be an opportunity for many companies to become proponent necessity for funding and business expansion. Sukûk publication announcement is an information for investors in order to assess it based on their investment decisions. In order to get the investment decisions, investors often based on the signals that had been given by the company. That signal can caused the changes of demand and supply's shares. This study aims to find out the reaction of the stock from the Sukûk publication as indicated by the presence of abnormal returns around the date of publication and the Trading Volume Activity (TVA) difference which is occured before and after Sukûk publication.

This study uses event study approach, it carries out on 11 issuer stock of Sukûk publisher which is listing in Indonesia Stock Exchange period: 2008-2012. This study also uses observation period for 81 days, they are $t-10$ (70 days before publication), $t$ - 0 (event date) and $t+10$ (10 days after publication). The hypothesis calibration of this thesis uses a one sample $t$ - test and paired $t$ - test.

The results of this study is based on a statistical test with a significance level (a) $=5 \%$ resulted AAR which was in a significantly positive on $t-2$ at 0.03711 and significantly negative at $t+9$ of 0.03 . In contrast with TVA, the statistic results showed probability value of 0.026 , which means there is a significant different of trading volume activity before and after of Sukûk publication. The lack of information about Sukûk also caused there is significant AAR reaction only in some poriods of observation and significant negative TVA .
\end{abstract}

Keywords : Sukûk, Abnormal Return, Trading Volume Activity

\section{PENDAHULUAN}

\section{A. Latar Belakang}

Dewasa ini, muncul salah satu instrumen investasi berupa sukûk atau yang dikenal dengan obligasi syariah. Perkembangan sukûk di dunia diawali dengan penerbitan sovereign sukûk menggunakan struktur ijarah pada September 2001 yang diterbitkan oleh pemerintah Bahrain (Central Bank of Bahrain) sebesar USD 100 Juta, kemudian diikuti oleh Negara- Negara GCC (Gulf Cooperation Council) yang menerbitkan sovereign Sukûk. Dilanjutkan dengan perkembangan penerbitan sukûk oleh perusahaan swasta (corporate sukûk) dan mendominasi pasar sukûk global pada tahun 2008 sebesar $86,4 \%$ (www.standartandpoors.com). Ahmed (2007) menyatakan bahwa instrumen keuangan Islam, khususnya sukûk, semakin menjadi pertimbangan penting - baik Muslim dan non-Muslim - dari perspektif investasi dan inovasi produk. Potensial besarnya karena sukûk mengubah dana masa depan menjadi dana saat ini. 
Di Indonesia, sukûk mulai muncul pada tahun 2002 dengan diterbitkannya sukûk PT. Indosat Tbk. Dengan menggunakan struktur mudharabah senilai Rp.100 milyar. SUkûk ini mengalami kelebihan permintaan (oversubscribed) dua kali lipat menjadi menjadi Rp.175 milyar (Endri, 2011). Perkembangan sukûk korporasi ini dari tahun ke tahun mengalami trend positif. Sejak pertama kali diterbitkannya sukûk pada tahun 2002 hingga tahun 2012, penerbitan sukûk terus mengalami peningkatan. Peningkatan ini terbilang menggembirakan karena dalam hanya dalam selang waktu sepuluh tahun peningkatan nilai emisi yang terjadi sebesar 5595 persen dari 175 milyar rupiah pada tahun 2002 menjadi 9790,4 miliar rupiah pada tahun 2012 (Bapepam, 2012)

Secara ekonomi, pendanaan melalui penerbitan sukûk menggantikan kebutuhan pendanaan dari lembaga keuangan, karena gabungan asset dijual kepada investor tanpa melibatkan perantara keuangan dan membuka jalan bagi pasar modal untuk perusahaan dan lembaga yang dalam perhitungan peringkat, tidak dapat mencapai pembiayaan yang efisien (Huda \& Nasution, 2007: 156). Penerbitan sukûk korporasi, dapat menjadi peluang bagi perusahaan untuk menjadi penyokong kebutuhan pendanaannya dan untuk perluasan usaha. Perusahaan dapat mendiversifikasi kebutuhan pendanaannya dengan menerbitkan sukûk selain dengan menerbitkan saham. Menurut Darsono dan Hestuningrum (2012) perusahaan dalam mencapai tujuan yang diinginkannya membutuhkan sumber pendanaan yang dapat diperoleh melalui pendanaan internal dan pendanaan eksternal. Keputusan pemilihan pendanaan perusahaan akan berpengaruh pada struktur modal perusahaan yang merupakan bauran sumber pendanaan jangka panjang. Struktur modal sangat penting bagi perusahaan untuk meningkatkan nilai perusahaan. Berkaitan dengan perubahan nilai perusahaan dan perubahan struktur modal perusahaan akan mempengaruhi pendapatan/return dari investor di pasar modal.

Investor di pasar modal akan mendasarkan keputusan investasinya pada berbagai informasi yang dimilikinya. Dalam mengambil keputusan investasi seorang investor harus juga peka terhadap informasi-informasi yang berkaitan dengan kondisi keuangan yang berhubungan dengan perusahaan atau industri tersebut Informasi yang dimiliki oleh investor lebih sedikit dibanding informasi yang dimiliki oleh pihak manajemen, hal ini disebut sebagai informasi yang tidak simetris (asymetric information). Investor mengambil keputusan untuk berinvestasi, seringkali dengan mendasarkan pada sinyal yang diberikan oleh perusahaan, salah satunya adalah informasi yang terkandung dalam pengumuman penerbitan obligasi syariah.

Pengumuman penerbitan sukûk dapat berpengaruh pada kegiatan investasi para investor, karena hal ini 
dapat menjadi sinyal bagi investor untuk mengetahui kondisi perusahaan saat ini dan perkiraan yang terjadi di masa yang akan datang, Informasi tersebut akan dianalisis oleh investor, apakah akan berdampak positif atau negatif bagi perusahaan. Hal ini berkaitan dengan tingkat risiko perusahaan yang diakibatkan oleh penerbitan sukûk maupun prospek kegiatan investasi yang dikelola perusahaan penerbit, apakah menambah nilai perusahaan atau tidak. Berdasarkan dua aspek tersebut, penerbitan sukûk yang direspon baik di pasar modal akan membawa keuntungan bagi perusahaan dan bagi pemegang saham yang akan tercermin dalam perubahan harga saham dan return saham. Sehingga dimungkinkan adanya abnormal return yang akan berdampak pada perubahan harga saham dan aktivitas volume perdagangan saham (trading volume activity).

Informasi ini akan direaksi oleh investor yang secara metodologis disebut sebagai event study. Tandelilin (2010) menjelaskan bahwa untuk melihat adanya reaksi pasar dapat dilihat melalui adanya abnormal return. Dalam hal ini, jika terdapat adanya abnormal return yang terjadi disekitar pengumuman informasi corporate action menunjukkan bahwa terdapat reaksi pasar yang positif terhadap informasi, jika sebaliknya, tidak terdapat abnormal return yang terjadi disekitar pengumuman informasi corporate action menunjukkan bahwa terdapat reaksi pasar yang negatif. Kecepatan reaksi pasar berhubungan dengan efisiensi informasi, sedangkan ketepatan reaksi pasar terkait dengan efisiensi keputusan investasi (Tandelilin, 2010).

Berdasarkan latar belakang tersebut, penelitian ini dilakukan untuk mengetahui apakah terdapat reaksi pasar saham dari adanya corporate action berupa penerbitan sukûk serta perbedaan likuiditas saham. Reaksi pasar saham tercermin dari return saham. Untuk mengukur reaksi pasar saham, peneliti menggunakan proksi AAR (Average Abnormal Return), dan dalam mengukur likuiditas saham menggunakan proksi TVA (Trading Volume Activity).

\section{B. Rumusan Masalah}

Berdasarkan latar belakang yang telah dijelaskan diatas maka rumusan masalah yang diangkat dalam penelitian ini adalah sebagai berikut:

1. Apakah terdapat reaksi pasar saham yang ditunjukkan dengan variabel AAR (Average Abnormal Return) atas penerbitan sukûk?

2. Apakah terdapat perbedaan TVA (Trading Volume Activity) sebelum dan sesudah penerbitan sukûk

\section{Tujuan Penelitian}

Tujuan yang ingin dicapai dalam penelitian ini adalah:

1. Untuk mengetahui apakah terdapat reaksi pasar saham yang signifikan yang ditunjukkan dengan variabel AAR (Average Abnormal Return) atas penerbitan sukûk. 
2. Untuk mengetahui perbedaan TVA (Trading Volume Activity) yang signifikan pada sebelum dan sesudah penerbitan sukûk.

\section{LANDASAN TEORI PENGEMBANGAN HIPOTESIS}

DAN

Reaksi pasar mengukur kecepatan pasar untuk bereaksi dengan cepat dan benar atas sebuah informasi (Tandelilin, 2010). Artinya bahwa ketika terdapat suatu informasi baru yang dipublikasikan di pasar, maka hal ini akan direspon pelaku pasar/investor yang disebut reaksi pasar. Informasi atau fakta material adalah informasi atau fakta penting dan relevan mengenai peristiwa, kejadian atau fakta yang dapat mempengaruhi harga efek pada Bursa Efek atau keputusan pemodal, calon pemodal atau pihak lain yang berkepentingan atas informasi atau fakta tersebut (UU No. 8 Tahun 1995 Tentang Pasar Modal pasal 1 ayat 4$)$.

Informasi yang relevan diklasifikasikan menjadi 3 tipe, yaitu (1) informasi mengenai perubahan harga di waktu yang lalu (past price changes), (2) informasi yang tersedia kepada publik (public information), dan (3) informasi yang tersedia kepada publik maupun tidak (public and private information) (Fama dalam Husnan (2004:265)).

Reaksi yang terjadi berupa reaksi positif dan reaksi negatif. Informasi tersebut digunakan investor untuk referensi dalam melakukan keputusan investasinya. Kecepatan reaksi pasar berhubungan dengan efisiensi informasi, sedangkan ketepatan reaksi pasar terkait dengan efisiensi keputusan investasi (Tandelilin, 2010).

Tandelilin (2010) menjelaskan bahwa untuk melihat adanya reaksi pasar dapat dilihat melalui adanya abnormal return. Jika terdapat adanya abnormal return yang terjadi disekitar pengumuman informasi corporate action menunjukkan bahwa terdapat reaksi pasar yang positif terhadap informasi, jika sebaliknya, tidak terdapat abnormal return yang terjadi disekitar pengumuman informasi corporate action menunjukkan bahwa terdapat reaksi pasar yang negatif.

Pengukuran reaksi pasar atas suatu peristiwa (event) seperti yang dikemukakan Jogiyanto (2003:352), informasi justru menjadi variabel yang akan dilihat hubungannya dengan perubahan harga-harga saham/return saham atau perilaku harga saham. Tetapi pada hal ini, informasi yang berkaitan dengan suatu peristiwa perlu ditelaah lebih lanjut. Suad Husnan (2003:267) dalam kaitannya dengan efisiensi pasar menyatakan, bahwa apa yang disebut informasi baru tidaklah, per definisi, tetapi yang bisa diperkirakan sebelumnya. Dengan kata lain, apabila harga saham mencerminkan semua informasi yang bisa diperkirakan, maka perubahan harga saham hanyalah mencerminkan informasi yang tidak bisa diperkirakan.

Kandungan informasi dari suatu pengumuman (event) tidak hanya berpengaruh pada harga tapi juga pada 
volume perdagangan saham. Volume perdagangan merupakan salah satu indikator yang digunakan untuk melihat reaksi pasar terhadap kejadian atau informasi yang berkaitan dengan suatu saham. Volume merefleksikan perubahan dalam pengharapan investor dalam tataran individual. Volume perdagangan saham dapat digunakan oleh investor untuk melihat apakah saham yang dibeli tersebut merupakan saham yang aktif diperdagangkan di pasar atau sebaliknya (Meidawati dan Harimawan, 2004). Saham yang aktif perdagangannya sudah pasti memiliki volume perdagangan yang besar dan saham dengan volume yang besar akan menghasilkan return saham yang tinggi. (Chordia, 2000) dalam Lestari (2011).

Perubahan volume perdagangan diukur dengan aktivitas volume perdagangan saham atau disebut dengan Trading Volume Activity (TVA). TVA merupakan instrument yang dapat digunakan untuk melihat reaksi pasar modal terhadap informasi melalui parameter perubahan volume perdagangan saham (Fatmawati dan Asri, 1999).

Ditinjau dari fungsinya Trading Volume Activity (TVA) merupakan suatu variasi dari event study. TVA merupakan perbandingan antara jumlah saham yang diperdagangkan pada waktu tertentu dengan jumlah saham perusahaan yang beredar pada periode tertentu. Besar kecilnya perubahan rata-rata TVA antara sebelum dan sesudah penerbitan sukûk merupakan ukuran besar kecilnya akibat yang ditimbulkan oleh adanya penerbitan sukûk terhadap volume perdagangan saham.

Sukmaningrum (2009) menyatakan mengenai kaitan antara informasi mengenai penerbitan obligasi konvensional dengan return saham sebagai berikut:

Return saham diasumsikan mengalami perubahan ketika ada informasi baru dan diserap oleh pasar. Apabila para pemodal (investor) menggunakan informasi yang berupa pengumuman penerbitan obligasi dalam kegiatannya, maka publikasi pengumuman penerbitan obligasi tersebut akan memberikan dampak berupa return saham apabila dibandingkan dengan hari-hari diluar pengumuman.

Pendapat serupa dinyatakan oleh Afaf (2007) sebagai berikut:

Penerbitan obligasi adalah salah satu bentuk kebijakan perusahaan yang akan berdampak pada terjadinya perubahan struktur modal perusahaan. Apabila informasi diterbitkannya obligasi oleh perusahaan merupakan informasi yang memiliki makna bagi investor, maka akan tercermin dalam perubahan harga saham yang akan menghasilkan return.

Sejalan dengan pendapatpendapat di atas, maka apabila informasi diterbitkannya obligasi syariah (sukûk) oleh perusahaan merupakan informasi yang memiliki makna bagi pasar, maka akan tercermin dalam perubahan harga saham 
yang akan menghasilkan return yang optimal, dan jika direspons sebaliknya, maka pengumuman tersebut tidak menghasilkan return yang optimal.

Berdasarkan latar belakang masalah, perumusan masalah, dan landasan teori yang telah dipaparkan, maka dalam penelitian ini akan dirumuskan beberapa hipotesis. Adapun hipotesis pada penelitian ini yaitu :

$\mathrm{H1}$ : Terdapat Average Abnormal Return (AAR) yang signifikan di sekitar tanggal pengumuman penerbitan sukûk,

H2: Terdapat perbedaan Abnormal Trading Volume Activity (TVA) yang signifikan pada sebelum dan setelah penerbitan sukûk.

\section{METODE PENELITIAN}

Penelitian dengan judul reaksi pasar atas penerbitan sukûk yang listing di Bursa Efek Indonesia periode 2008-2012 adalah penelitian yang menggunakan teknik penelitian studi peristiwa (event study). Jogiyanto (2005) penelitian event study adalah penelitian yang mempelajari reaksi pasar terhadap terjadinya suatu peristiwa yang informasinya dipublikasikan di pasar. Studi ini dapat digunakan untuk mengungkapkan kandungan informasi dari suatu peristiwa (Bhattacharya et.al, 200). Peristiwa yang di uji dalam penelitian ini adalah pengumuman penerbitan sukûk dan melihat reaksi pasar yang ditunjukkan dengan adanya abnormal return yang signifikan pada tanggal pengumuman penerbitan sukûk.

Penelitian ini menggunakan pendekatan kuantitatif, menggunakan periode pengamatan (event windows) dengan model Market-Adjusted Model yang tidak perlu menggunakan periode estimasi, karena return sekuritas yang diestimasi adalah sama dengan return indeks pasar (Jogiyanto, 2010:591). Penelitian ini mencoba menjelaskan apakah ada pergerakan return yang abnormal dan aktivitas perdagangan saham (trading volume activity) disekitar tanggal pengumuman penerbitan sukûk. Pemenggunakan analisa statistik untuk menguji hipotesis. Penelitian ini menitikberatkan pada pengujian hipotesis, mengukur variabel yang sedang diteliti dan menghasilkan kesimpulan yang dapat digeneralisasikan. Berdasarkan rumusan masalah dan hipotesis penelitian, maka variabel-variabel dalam penelitian ini dapat diidentifikasikan antara lain, peristiwa (event) pengumuman penerbitan sukûk, variabel ini merupakan acuan pengukuran variabel lainnya dimana harga saham saat event date dijadikan t-0; AAR (Average Abnormal Return), variabel ini merupakan rata-rata selisisih actual return dan expected return, ATVA ( Abnormal Trading Volume Activity) saham variabel ini merupakan selisisih actual TVA dan expected TVA, TVA sendiri merupakan perbandingan volume perdagangan dan listed share saham di BEI.

Pengujian hipotesis dilakukan dengan uji statistik t-test untuk menguji apakah variabel yang digunakan dalam penelitian ini secara parsial memiliki pengaruh signifikan, dan uji statistik paired 
sample t-test untuk menguji apakah terdapat perbedaan yang signifikan pada variabel pada sebelum dan sesudah penerbitan sukûk dengan taraf keyakinan $95 \%$ dan $(a)=5 \%$.

\section{DESKRIPSI HASIL DAN PEMBAHASAN}

Pembahasan hasil penelitian didasarkan pada uji one sample t-test untuk menguji hipotesis tentang reaksi saham perusahaan penerbit sukûk serta uji paired t-test untuk menguji hipotesis perbedaan aktivitas volume perdagangan saham perusahaan pada sebelum dan setelah penerbitan sukûk.

Pada tabel 1. terdapat fluktuasi AAR dengan variasi yang mencolok setelah penerbitan sukûk karena terdapat abnormal return negatif sebesar 60 persen pada hari-hari setelah diterbitkannya sukûk. Hal ini dikarenakan sebagian besar investor belum menganggap bahwa penerbitan sukûk ditangkap sebagai sinyal positif sebagai alternatif pendanaan bagi perusahaan. Reaksi tersebut secara statistik direspon negatif oleh pasar, dikarenakan investor masih menganggap sukûk sama dengan obligasi, dimana obligasi hanya akan meningkatan leverage perusahaan yang nantinya penggunaan hutang tersebut dapat menurunkan nilai saham karena adanya pengaruh biaya kepailitan (default risk) dan biaya bunga yang ditimbulkan dari adanya penggunaan hutang.
Tabel 1.

Tabel Hasil Uji Statistik Average Abnormal Return (AAR) One Sample t-Test

\begin{tabular}{|c|c|c|c|c|}
\hline \multirow{2}{*}{$\begin{array}{l}\text { Event } \\
\text { Window }\end{array}$} & \multirow{2}{*}{$\begin{array}{c}\begin{array}{c}\text { Average } \\
\text { Abnormal } \\
\text { Return) }\end{array} \\
\text { AAR } \\
\end{array}$} & \multicolumn{2}{|c|}{ Test Value $=0$} & \multirow[t]{2}{*}{ Keterangan } \\
\hline & & $\begin{array}{l}\text { Sig.(2- } \\
\text { tailed) }\end{array}$ & $t$ & \\
\hline $\mathrm{t}-70$ & 0.0003 & 0.96 & 0.0498 & $\mathrm{H}_{0}$ Diterima \\
\hline$t-69$ & 0.0055 & 0.63 & 0.5023 & $\mathrm{H}_{0}$ Diterima \\
\hline$t-68$ & 0.0009 & 0.85 & 0.1898 & $\mathrm{H}_{0}$ Diterima \\
\hline$t-67$ & 0.0044 & 0.41 & 0.8693 & $\mathrm{H}_{0}$ Diterima \\
\hline$t-66$ & 0.0149 & 0.03 & 2.4624 & $\mathrm{H}_{0}$ Ditolak \\
\hline$t-65$ & 0.0022 & 0.8 & 0.2545 & $\mathrm{H}_{0}$ Diterima \\
\hline$t-64$ & 0.0017 & 0.86 & 0.1852 & $\mathrm{H}_{0}$ Diterima \\
\hline$t-63$ & -0.0173 & 0.05 & -2.1759 & $\mathrm{H}_{0}$ Diterima \\
\hline$t-62$ & 0.0046 & 0.51 & 0.6792 & $\mathrm{H}_{0}$ Diterima \\
\hline$t-61$ & 0.0032 & 0.59 & 0.5508 & $\mathrm{H}_{0}$ Diterima \\
\hline$t-60$ & 0.0005 & 0.94 & 0.076 & $\mathrm{H}_{0}$ Diterima \\
\hline$t-59$ & -0.0112 & 0.23 & -1.2744 & $\mathrm{H}_{0}$ Diterima \\
\hline$t-58$ & 0.0134 & 0.02 & 2.9264 & $\mathrm{H}_{0}$ Ditolak \\
\hline$t-57$ & 0.0101 & 0.11 & 1.7477 & $\mathrm{H}_{0}$ Diterima \\
\hline$t-56$ & -0.0064 & 0.6 & -0.5445 & $\mathrm{H}_{0}$ Diterima \\
\hline$t-55$ & -0.0245 & 0.31 & -1.0622 & $\mathrm{H}_{0}$ Diterima \\
\hline$t-54$ & 0.018 & 0.18 & 1.4249 & $\mathrm{H}_{0}$ Diterima \\
\hline$t-53$ & 0.0048 & 0.61 & 0.5301 & $\mathrm{H}_{0}$ Diterima \\
\hline$t-52$ & -0.0013 & 0.84 & -0.2117 & $\mathrm{H}_{0}$ Diterima \\
\hline$t-51$ & -0.0206 & 0.2 & -1.3559 & $\mathrm{H}_{0}$ Diterima \\
\hline$t-50$ & 0.0067 & 0.28 & 1.1304 & $\mathrm{H}_{0}$ Diterima \\
\hline$t-49$ & 0.0295 & 0.04 & 2.4247 & $\mathrm{H}_{0}$ Ditolak \\
\hline $\mathrm{t}-48$ & 0.0104 & 0.47 & 0.7593 & $\mathrm{H}_{0}$ Diterima \\
\hline $\mathrm{t}-47$ & -0.0014 & 0.88 & -0.1498 & $\mathrm{H}_{0}$ Diterima \\
\hline$t-46$ & -0.0045 & 0.65 & -0.4748 & $\mathrm{H}_{0}$ Diterima \\
\hline$t-45$ & 0.0106 & 0.1 & 1.8368 & $\mathrm{H}_{0}$ Diterima \\
\hline$t-44$ & 0.0014 & 0.61 & 0.5266 & $\mathrm{H}_{0}$ Diterima \\
\hline$t-43$ & -0.0238 & 0.23 & -1.2766 & $\mathrm{H}_{0}$ Diterima \\
\hline$t-42$ & -0.0038 & 0.58 & -0.5753 & $\mathrm{H}_{0}$ Diterima \\
\hline$t-41$ & -0.0099 & 0.14 & -1.6173 & $\mathrm{H}_{0}$ Diterima \\
\hline$t-40$ & 0.0031 & 0.66 & 0.4553 & $\mathrm{H}_{0}$ Diterima \\
\hline$t-39$ & -0.0031 & 0.69 & -0.4059 & $\mathrm{H}_{0}$ Diterima \\
\hline$t-38$ & -0.0113 & 0.35 & -0.9754 & $\mathrm{H}_{0}$ Diterima \\
\hline$t-37$ & 0.0005 & 0.94 & 0.0819 & $\mathrm{H}_{0}$ Diterima \\
\hline$t-36$ & -0.0076 & 0.32 & -1.0424 & $\mathrm{H}_{0}$ Diterima \\
\hline$t-35$ & -0.0294 & 0.08 & -1.986 & $\mathrm{H}_{0}$ Diterima \\
\hline$t-34$ & -0.0203 & 0.05 & -2.2013 & $\mathrm{H}_{0}$ Diterima \\
\hline$t-33$ & -0.0017 & 0.91 & -0.1135 & $\mathrm{H}_{0}$ Diterima \\
\hline$t-32$ & 0.006 & 0.63 & 0.4958 & $\mathrm{H}_{0}$ Diterima \\
\hline$t-31$ & -0.0262 & 0.03 & -2.4417 & $\mathrm{H}_{0}$ Ditolak \\
\hline$t-30$ & 0.0092 & 0.1 & 1.7957 & $\mathrm{H}_{0}$ Diterima \\
\hline$t-29$ & -0.0046 & 0.56 & -0.6008 & $\mathrm{H}_{0}$ Diterima \\
\hline$t-28$ & -0.0042 & 0.36 & -0.9532 & $\mathrm{H}_{0}$ Diterima \\
\hline$t-27$ & -0.0096 & 0.6 & -0.5354 & $\mathrm{H}_{0}$ Diterima \\
\hline$t-26$ & 0.0233 & 0.02 & 2.7919 & $\mathrm{H}_{0}$ Ditolak \\
\hline$t-25$ & 0.017 & 0.17 & 1.4858 & $\mathrm{H}_{0}$ Diterima \\
\hline$t-24$ & -0.0108 & 0.2 & -1.3788 & $\mathrm{H}_{0}$ Diterima \\
\hline$t-23$ & -0.0154 & 0.09 & $\begin{array}{l}-1.8477 \\
\end{array}$ & $\mathrm{H}_{0}$ Diterima \\
\hline$t-22$ & -0.0128 & 0.37 & -0.9383 & $\mathrm{H}_{0}$ Diterima \\
\hline$t-21$ & 0.0037 & 0.8 & 0.2537 & $\mathrm{H}_{0}$ Diterima \\
\hline$t-20$ & 0.0071 & 0.23 & 1.2874 & $\mathrm{H}_{0}$ Diterima \\
\hline$t-19$ & 0.0046 & 0.37 & 0.9451 & $\mathrm{H}_{0}$ Diterima \\
\hline$t-18$ & 0.0114 & 0.21 & 1.3435 & $\mathrm{H}_{0}$ Diterima \\
\hline$t-17$ & -0.0022 & 0.81 & -0.2419 & $\mathrm{H}_{0}$ Diterima \\
\hline$t-16$ & 0.0028 & 0.62 & 0.5129 & $\mathrm{H}_{0}$ Diterima \\
\hline$t-15$ & 0.0033 & 0.64 & 0.4891 & $\mathrm{H}_{0}$ Diterima \\
\hline$t-14$ & -0.0007 & 0.92 & -0.1042 & $\mathrm{H}_{0}$ Diterima \\
\hline$t-13$ & 0.0034 & 0.64 & 0.4878 & $\mathrm{H}_{0}$ Diterima \\
\hline$t-12$ & -0.0047 & 0.49 & -0.7175 & $\mathrm{H}_{0}$ Diterima \\
\hline$t-11$ & 0.0018 & 0.83 & 0.2199 & $\mathrm{H}_{0}$ Diterima \\
\hline$t-10$ & -0.0008 & 0.88 & -0.1497 & $\mathrm{H}_{0}$ Diterima \\
\hline$t-9$ & 0.0023 & 0.72 & 0.3631 & $\mathrm{H}_{0}$ Diterima \\
\hline$t-8$ & 0.0022 & 0.48 & 0.7318 & $\mathrm{H}_{0}$ Diterima \\
\hline$t-7$ & 0.0094 & 0.28 & 1.1391 & $\mathrm{H}_{0}$ Diterima \\
\hline$t-6$ & -0.0061 & 0.48 & -0.7384 & $\mathrm{H}_{0}$ Diterima \\
\hline$t-5$ & -0.0033 & 0.76 & -0.308 & $\mathrm{H}_{0}$ Diterima \\
\hline$t-4$ & 0.0041 & 0.71 & 0.382 & $\mathrm{H}_{0}$ Diterima \\
\hline$t-3$ & -0.0252 & 0.23 & -1.2873 & $\mathrm{H}_{0}$ Diterima \\
\hline$t-2$ & 0.0399 & 0.04 & 2.2931 & $\mathrm{H}_{0}$ Ditolak \\
\hline$t-1$ & -0.0046 & 0.41 & -0.8556 & $\mathrm{H}_{0}$ Diterima \\
\hline$t-0$ & 0.0011 & 0.79 & 0.2715 & $\mathrm{H}_{0}$ Diterima \\
\hline$t+1$ & -0.0043 & 0.59 & -0.5631 & $\mathrm{H}_{0}$ Diterima \\
\hline$t+2$ & -0.0015 & 0.86 & -0.1861 & $\mathrm{H}_{0}$ Diterima \\
\hline$t+3$ & -0.0023 & 0.82 & -0.2285 & $\mathrm{H}_{0}$ Diterima \\
\hline$t+4$ & -0.0022 & 0.82 & -0.2393 & $\mathrm{H}_{0}$ Diterima \\
\hline$t+5$ & -0.0046 & 0.71 & -0.3882 & $\mathrm{H}_{0}$ Diterima \\
\hline
\end{tabular}




\begin{tabular}{|c|c|c|c|c|}
\hline$t+6$ & 0.002 & 0.8 & 0.2582 & $\mathrm{H}_{0}$ Diterima \\
\hline$t+7$ & -0.0025 & 0.78 & -0.2842 & $\mathrm{H}_{0}$ Diterima \\
\hline$t+8$ & 0.004 & 0.49 & 0.7125 & $\mathrm{H}_{0}$ Diterima \\
\hline$t+9$ & 0.0305 & 0 & 4.5371 & $\mathrm{H}_{0}$ Ditolak \\
\hline$t+10$ & 0.1415 & 0.26 & 1.1868 & $\mathrm{H}_{0}$ Diterima \\
\hline
\end{tabular}

Sumber: Data Sekunder, diolah (2014)

Belum adanya data informasi pasar yang sesuai dengan syariah cukup mempengaruhi investor dalam mengambil keputusan bertransaksi sukûk korporasi. Hal ini dikarenakan investor secara tidak langsung akan selalu membandingkan return antara sukûk dengan instrumen konvensional lainnya. Investor belum memahami sepenuhnya, bahwa dengan pendanaan melalui sukûk dapat meningkatkan nilai perusahaan yang secara otomatis akan meningkatkan kekayaan pemegang saham.

Pada tabel 1., Selama periode pengamatan 81 hari perdagangan (t-70) sampai dengan $(t+10)$ terdapat beberapa data dengan nilai probabilitas lebih kecil dari $(a)=5 \%$. Pada periode pengamatan (t-66) dengan nilai probabilitas sebesar 0.033, (t-58) dengan nilai probabilitas sebesar 0.015, (t-49) dengan nilai probabilitas sebesar 0.036, (t-31) dengan nilai probabilitas sebesar 0.035, (†-26) dengan nilai probabilitas sebesar 0.019, (†2) dengan nilai probabilitas sebesar 0.044. Berdasarkan nilai probabilitas uji hipotesis tersebut adalah $\mathrm{H}_{0}$ ditolak dan $\mathrm{H}_{1}$ diterima. Kesimpulan dari hasil uji tersebut adalah terdapat average abnormal return yang terjadi signifikan secara nyata pada harihari tersebut. Hal ini menunjukkan adanya news release mengenai adanya pengumuman penting berupa penerbitan sukûk yang telah dilepas sebelum tanggal efektif penerbitan, tetapi adanya respon fluktuatif menunjukkan tidak semua investor mengetahui bahwa perusahaan akan benar-benar menerbitkan sukûk dalam waktu dekat. Average abnormal return yang signifikan yang terjadi pada hari sekitar penerbitan juga menunjukkan bahwa telah ada kebocoran informasi bahwa emiten akan melakukan corporate action berupa penerbitan sukûk pada tanggal efektif penerbitan, hal ini dikarenakan adanya asymetric information, dimana sebagian calon investor sudah mengetahui terlebih dahulu informasi bahwa perusahaan akan menerbitkan sukûk.

Selain itu pada periode pengamatan setalah penerbitan sukûk tepatnya pada $\uparrow+10$ ditemukan nilai probabilitas sebesar 0,001 lebih kecil dari (a) $=5 \%$. Berdasarkan nilai probabilitas uji hipotesis tersebut adalah $\mathrm{H}_{0}$ ditolak dan $\mathrm{H}_{1}$ diterima. Kesimpulan dari hasil uji tersebut adalah terdapat abnormal return yang signifikan pada hari tersebut, hal ini dikarenakan informasi membutuhkan waktu untuk direfleksikan dengan harga saham selain itu investor sedang mengevaluasi kandungan informasi yang terdapat pada penerbitan sukûk.

Sesuai dengan konsep efisiensi pasar secara informasi, AAR yang fluktuatif tersebut menunjukkan bahwa investor menganalisis corporate action berupa penerbitan sukûk dalam mendasarkan keputusan investasinya untuk membeli, membiarkan atau melepaskan saham 
yang dimikinya. Nilai AAR yang positif menunjukkan bahwa penerbitan sukûk merupakan informasi positif (good news) bagi sebagian investor saham dalam memprospek investasinya, informasi tersebut dinilai oleh investor sebagai sinyal yang baik, dengan harapan bahwa perusahaan penerbit sukûk mempunyai prospek jangka panjang lebih baik. Sedangkan, AAR dengan nilai negatif mengindikasikan bahwa investor menilai perusahaan dari sisi risiko baik risiko sistematis (systematic risk) maupun risiko tidak sistematis (unsystematic risk) perusahaan dari penerbitan sukûk.

Pada tabel 1. terdapat fluktuasi AAR dengan variasi yang mencolok setelah penerbitan sukûk karena terdapat abnormal return negatif sebesar 60 persen pada hari-hari setelah diterbitkannya sukûk. Hal ini dikarenakan sebagian besar investor belum menganggap bahwa penerbitan sukûk ditangkap sebagai sinyal positif sebagai alternatif pendanaan bagi perusahaan. Reaksi tersebut secara statistik direspon negatif oleh pasar, dikarenakan investor masih menganggap sukûk sama dengan obligasi, dimana obligasi hanya akan meningkatan leverage perusahaan yang nantinya penggunaan hutang tersebut dapat menurunkan nilai saham karena adanya pengaruh biaya kepailitan (default risk) dan biaya bunga yang ditimbulkan dari adanya penggunaan hutang. Belum adanya data informasi pasar yang sesuai dengan syariah cukup mempengaruhi investor dalam mengambil keputusan bertransaksi sukûk korporasi. Hal ini dikarenakan investor secara tidak langsung akan selalu membandingkan return antara sukûk dengan instrumen konvensional lainnya. Investor belum memahami sepenuhnya, bahwa dengan pendanaan melalui sukûk dapat meningkatkan nilai perusahaan yang secara otomatis akan meningkatkan kekayaan pemegang saham.

Tabel 2.

Tabel Hasil Uji Statistik Paired t-Test Correlations Pada Average Abnormal Trading Volume Activity (AATVA) Sumber: Data Sekunder, diolah (2014)

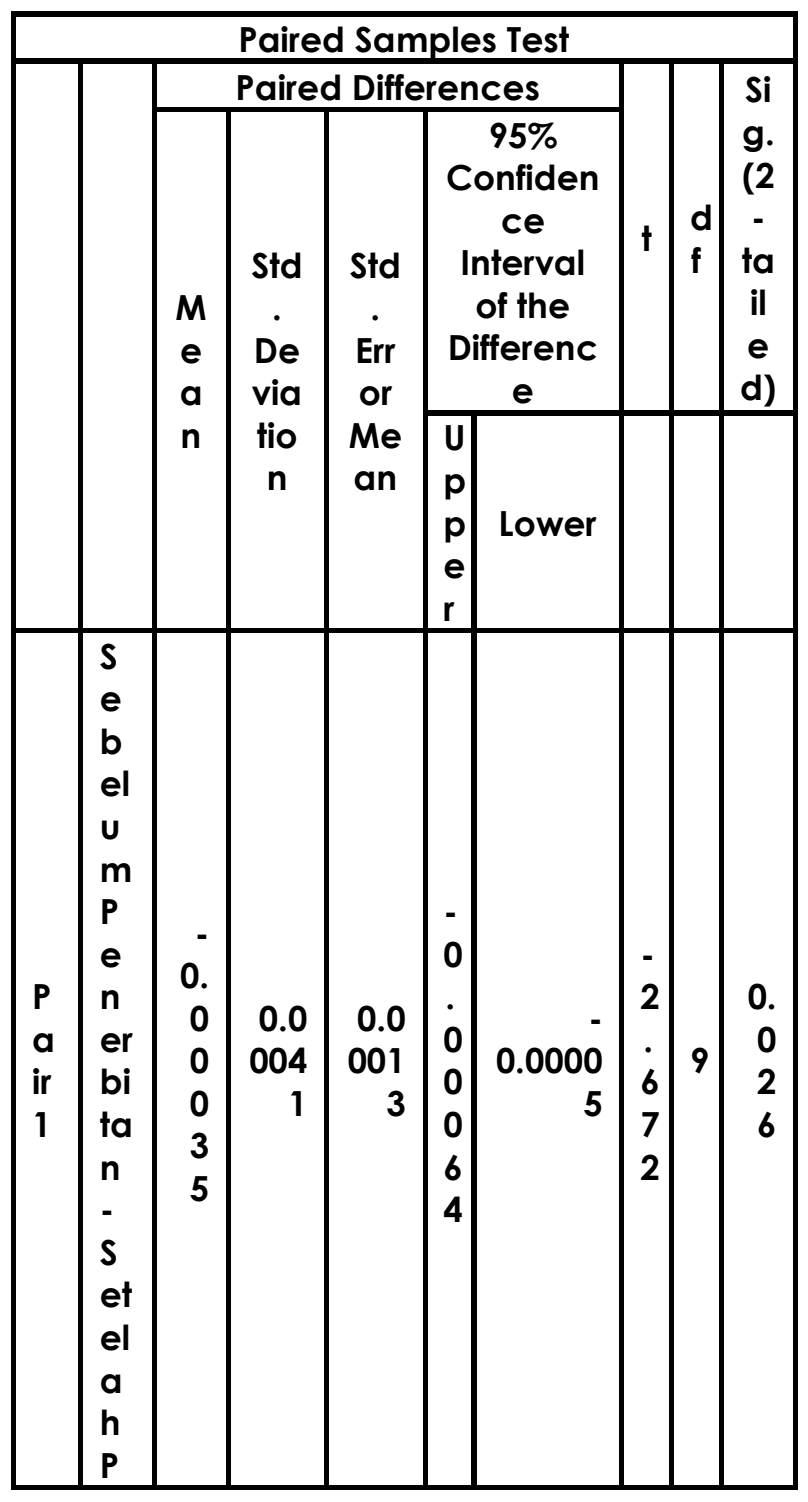




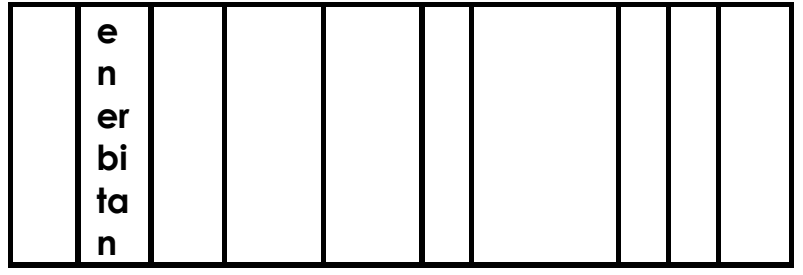

Pada tabel 2. diatas dapat diketahui dari hasil dari pengujian paired sample ttest menunjukkan bahwa average abnormal trading volume activity sebelum dan sesudah penerbitan sukûk memiliki nilai probabilitas 0.026 yang berarti nilai probabilitasnya lebih kecil dari $(a)=5 \%$. Hasil uji hipotesis berdasarkan nilai probabilitas tersebut adalah $\mathrm{H}_{0}$ diterima dan $\mathrm{H}_{1}$ ditolak. Dapat disimpulkan bahwa terdapat perbedaan average abnormal trading volume activity yang signifikan pada sebelum dan setelah penerbitan sukûk. Hal ini berarti, secara kumulatif terjadi kenaikan dan penurunan trading volume activity yang signifikan selama periode pengamatan pada emiten yang menerbitkan sukûk. Signifikansi perbedaan abnormal trading volume activity dimungkinkan investor saham mengantisipasi kandungan dan risiko yang ditimbulkan atas penerbitan sukûk, dikarenakan jika dalam jangka panjang, perusahaan mengalami kepailitan maka investor pemegang sukûk dan obligasi akan menjadi prioritas pertama dalam pembayaran kewajibannya dibanding pemegang sekuritas lainnya. Selain itu, terdapat "second best choice" yang terjadi akibat kurang liquidan sukûk di pasar sekuder, ini menjadi pertimbangan bagi investor dalam membeli sukûk sebab mereka harus menahannya hingga jatuh tempo. Masih terbatasnya penerbitan sukûk korporasi di Indonesia baik dari aspek jumlah, variasi tenor maupun jenis akad. Hal tersebut juga dievaluasi oleh investor saham dalam menilai penerbitan sukûk yang dilakukan perusahaan, dilihat dari risiko yang terkandung dalam penerbitan sukûk sehingga investor mengantisipasi penerbitan sukûk dan menganggap bahwa penerbitan sukûk tidak menambah nilai perusahaan.

Efisiensi pasar modal sangat berkaitan dengan persebaran informasi yang terdapat dipasar modal, serta seberapa cepat informasi tersebut diserap dan mendapatkan feedback dari investor. Informasi tersebut sangat diperlukan sebagai alternatif dalam pengambilan keputusan investasi, sehingga semakin cepat pasar modal melakukan reaksi terhadap informasi baru, maka efisien pula pasar modal tersebut (Hendrawaty, 2007 dalam Lestari, 2011). Pada hasil pengujian AAR dan AATVA menunjukkan bahwa investor di Indonesia kurang bisa memberikan feedback cepat dalam mengevaluasi informasi yang diterimanya, dan juga karena sebagian investor menganggap bahwa penerbitan sukûk bukanlah good news sehingga tidak mengubah preferensi investor dalam keputusan investasinya.

Belum meratanya informasi dan kurangnya pengetahuan investor mengenai instrumen sukûk menjadi salah satu penyebabnya. Investor di pasar modal belum sepenuhnya terbiasa dengan sistem akad, bagi hasil, fee/ujrah dan margin pada sukûk. Sukûk dipandang 
seperti halnya obligasi, yang seringkali digunakan investor untuk membiayai kebutuhan jangka pendeknya atau membiayai hutang sebelumnya, tidak demikian pada sukûk dimana terdapat underlying asset, yang hanya dapat diterbitkan jika perusahaan akan melakukan ekspansi yang bertujuan untuk meningkatkan value perusahaan, yang otomatis akan meningkatkan kekayaan pemegang saham. Hal ini sejalan dengan yang dijelaskan dalam penelitian kajian pasar sekunder sukûk bahwa seharusnya adanya karateristik khusus sukûk yaitu adanya underlying asset, harga pasar wajar sukûk seharusnya menjadi lebih baik dibandingkan harga pasar wajar surat utang lainnya mengingat lebih rendahnya faktor risiko seperti finansial risk yaitu risiko yang ditanggung pemegang saham sebagai akibat dari penggunaan leverage keuangan atau sejauh mana sekuritas berpenghasilan tetap (utang dan saham preferen) yang digunakan dalam struktur modal perusahaan dan risiko kegagalan (default risk) yang ditanggung perusahaan karena semakin tinggi hutang dapat membuat semakin rendah kemampuan perusahaan untuk membayar hutang pada saat jatuh tempo dibandingkan dengan efek bersifat utang. Namun pada faktanya, metode penilaian harga pasar wajar sukûk saat ini tidak dibedakan dengan metode penilaian harga pasar wajar obligasi dan belum memasukkan faktor underlying asset sebagai salah satu variabel. Mayoritas karakter investor sukûk merupakan investor institusi lokal seperti Perusahaan Asuransi, Dana Pensiun, dan reksa dana terstruktur yang memiliki kecenderungan membeli untuk disimpan hingga jatuh tempo (hold to maturity) (Bapepam, 2012).

Selain itu, dari sisi makro ekonomi, pasar kevangan syariah di Indonesia tidak terlalu likuid. Penyebabnya, pangsa pasarnya yang relatif kecil, yaitu kurang dari 5\% dari seluruh sistem keuangan di Indonesia. Kecilnya pangsa pasar keuangan syariah ini diperkirakan menyebabkan pertumbuhan sukûk domestik yang terbatas. Masih terbatasnya penerbitan sukûk korporasi di Indonesia baik dari aspek jumlah, variasi tenor maupun jenis akad. Proporsi jumlah sukûk hanya 11,23\% dari total jumlah efek bersifat utang yang beredar. Sementara itu, dari sisi nilai, proporsi sukûk dari total efek bersifat utang yang beredar baru mencapai 4,32\% (Bapepam, 2011). Masalah lain, terkait dengan transaksi yang melibatkan investor sukûk karena sampai saat ini masih belum ada kepastian masalah perpajakan. Permasalahan perpajakan ini tidak hanya terkait dengan sukûk, namun menyangkut transaksi kevangan syariah secara keseluruhan. Isu yang paling mengemuka adalah adanya double taxation dalam transaksi keuangan syariah.

Penelitian ini sesuai dengan hasil penelitian sebelumnya oleh Mujahid dan Fitrijanti (2009) menungkapkan bahwa nilai dan rating penerbitan obligasi syariah (sukûk) hanya merupakan bagian kecil 
dari keseluruhan variabel makro yang turut mempengaruhi aktivitas perekonomian negara umumnya, dan perusahaan khususnya. Karena, menurut penelitian yang dilakukan Burnmeister dan McElroy (1988) dalam Michell Suharli (2004) melanjutkan penelitian Chen, Roll dan Ross yang hasilnya menyatakan terdapat hubungan yang kuat antara variabel makroekonomi terhadap return suatu saham. Walaupun begitu, nilai dan rating penerbitan obligasi syariah (sukûk) tetap patut diperhitungkan dalam pengambilan suatu keputusan investasi karena nilainya akan senantiasa berubah dari waktu ke waktu dan diprediksi akan semakin berkembang di masa yang akan datang. Nilai dan rating penerbitan obligasi syariah (sukûk) ini bisa saja akan berdampak pada harga saham perusahaan dalam beberapa waktu kedepan.

\section{SIMPULAN}

Berdasarkan hasil penelitian dengan judul Reaksi Pasar Atas Penerbitan Sukûk yang dilakukan pada emiten saham penerbit sukuk yang listing di Bursa Efek Indonesia (BEI) periode 2008-2012, maka dapat diambil beberapa kesimpulan sebagai berikut:

1. Terdapat Average Abnormal Return (AAR) selama periode pengamatan. AAR dengan nilai positif terdapat pada 43 hari periode pengamatan dan AAR bernilai negatif terdapat pada 38 hari periode pengamatan. Reaksi cukup besar terjadi pada hari sebelum penerbitan sukuk tepatnya pada periode pengamatan $\mathrm{t}-2$ sebesar 0.03711 . Reaksi pasar positif juga terjadi pada t-0 yaitu hari saat diterbitkannya sukûk sebesar 0.0011 . Setelah penerbitan sukûk terdapat Average Abnormal Return (AAR) yang signifikan pada t+9 sebesar 0.0305 .

2. Terdapat perbedaan Abnormal Trading Volume Activity (ATVA) pada sebelum dan setelah penerbitan sukuk selama periode pengamatan. Hasil penelitian terhadap abnormal trading volume activity dengan uji statistik paired t-test, rata-rata abnormal TVA sebelum penerbitan sukûk, terdapat perbedaan yang signifikan pada trading volume activity saham pada sebelum dan setelah penerbitan sukûk, dengan nilai probabilitas sebesar 0,02.

\section{DAFTAR PUSTAKA}

Accounting and Auditing Organisation for Islamic Financial Institution. 2004. Investment Sukûk. Sharia Standart. Bahrain.

Afaf, Nafiah. 2007. Analisis Pengaruh Pengumuman Penerbitan Obligasi Terhadap Return Saham di Bursa Efek Jakarta. Tesis S2 yang tidak dipublikasikan. Bogor Institut Pertanian Bogor.

Alwi, Syafaruddin. 1994. Alat-alat Analisis Dalam Pembelanjaan, Edisi Revisi/Keempat, Yogyakarta: Andi Offset.

Al-Quran dan Terjemahannya. 2003. Tafsir Fi Zhilalil Qur'an. Jilid 6. Jakarta: 
Gema Insani Press.

Ang, Robert. 1997. The Journal of Financial

Research. Buku Pintar Pasar Modal Indonesia Vol V : 3. Jakarta: Media Staff Indonesia The Journal of Financial Research. Vol $\vee: 3$

Anshori, Muslich, Iswati. 2009. Metodologi Penelitian Kuantitatif. Surabaya: Airlangga University Press.

Anwar, Choirul. 2004. Studi Peristiwa Reaksi Pasar terhadap Pemilihan Umum tanggal 5 April 2005 pada Bursa Efek Jakarta. Jurnal Ekonomi \& Bisnis No.2 Jilid 9

Badan Pengawas Pasar Modal dan Lembaga Keuangan. 2006. Peraturan No.IX.A.13 tentang Penerbitan Efek Syariah. Jakarta

Bodie, Zvi, Alex Kane, dan Alan J. Marcus. 1999. Investments. Fourth Edition. Boston: McGrae-Hill Inc.

Bhattacharya U, H, Doouk \& B. Jorgenson,2000, When Evement is Non An Event. The Curious Care of An Emerginal Market, Journal of Financial Economies Vol 55

Brigham, Eugene F. Dan Joel F. Houston. 1998. Fundamentals of Financial Management. Eight Edition. Florida: Harcourt Inc.

Budiarto, Arif Murtanto. 2002. Event Study: Telaah Metodologi dan Penerapannya di Bidang Ekonomi dan Keuangannya. Jurnal Bisnis dan Akuntansi. Vol 4, No.3: 295-320

Bursa Efek Indonesia (BEl). 2004. Studi tentang Investasi Syariah di Pasar Modal Indonesia. (Online) www.idx.co.id, diakses pada 16 Oktober 2013

Bursa Efek Indonesia. 2007. Mengenal Pasar Modal. (Online) www.idx.co.id, diakses pada 02 September 2013

Cheng, Wei, N. Visaltanachoti, dan P.Kesayan.2005. A stock market reaction following convertible Bond Issuance: evidenve from japan. International Journal of Business, Vol. 10: 323-339

Campbell, John Y, Andrew W Lo, dan A. Craig McKinlay. 1996. The Econometrics of Financial Markets. US: Princeton University Press

Darsono dan Ratri Dian H.2012. Pengaruh Karakteristik Perusahaan Terhadap Struktur Modal Perusahaan Manufaktur yang Terdaftar Pada Bursa Efek Indonesia. Volume I, No. 1. Diponegoro Journal of Accounting.

Dewan Syariah Nasional. 2002. Fatwa No.32/DSN/MUI/IX/2002 tentang Obligasi Syariah. (Online) www.bapepam.go.id diakses pada 01 November 2012

Dewan Syariah Nasional. 2002. Fatwa No.33/DSN/MUI/IX/2002 tentang Obligasi Syariah Mudhârabah. (Online) www.bapepam.go.id diakses pada 01 November 2012

Dewan Syariah Nasional. 2004. Fatwa No 40/DSN/MUI/X tentang Pasar Modal dan Pedoman Umum Penerapan Prinsip Syariah di Pasar Modal.

(Online) 
www.bapepam.go.id, diakses pada 1 November 2012.

Dewan Syariah Nasional. 2002. Fatwa No.41/DSN/MUI/IX/2002 tentang Obligasi Syariah ljarah. (Online) www.bapepam.go.id diakses pada 01 November 2012

Endri, 2011. Corporate Governance Terhadap Peringkat Sukûk Korporasi di Indonesia. Jurnal Keuangan dan Perbankan. Vol.15, No.2: 178-190

Elfakhani, Said, dan M. Kabir Hassan dan Yusuf Sidani, 2005. Comparative Performance of Islamic Versus Secular Mutual Funds. Lebanon

Fatmawati, Sri dan Marwan Asri. 1999. Pengaruh Stock Split terhadap Likuiditas saham yang diukur dengan besarnya Bid-ask spread di Bursa Efek Jakarta. Jurnal Ekonomi dan Bisnis Indonesia. Vol 14: 93-110

Foster, G. 1986. Financial Statement Analysis, 2nd edition. Engglewood Cliffs. New Jersey: Prentice Hall International

Hartono, dan Jogiyanto. 2003. Teori Portfolio dan Analisis Investasi. Yogyakarta: BPFE

Husnan, Suad. 1998. Dasar-dasar Teori Portofolio dan Analisis Sekuritas. Yogyakarta: UPP AMP YKPN.

International Organization of Securities Commissions. 2004. Islamic Capital Market Fact Finding Report. Report Of The Islamic Capital Market Task Force of The International
Organization Of Securities

Commissions. Spanyol

Jogiyanto. 2000. Teori Portfolio dan Analisis Investasi. Edisi Ketiga, Yogyakarta: Fakultas Ekonomi Universitas Gajah Mada.

Jogianto,2008, Teori Portofolio dan Analisis Investasi,Edisi Kelima, BPFE UGM, Yogyakarta

Jones, Charles P. 2002. Investments. Eight Edition. New York: John Wiley \& Sons, Inc.

Karim, Adiwarman. 2004. Bank Islam: Analisis Fiqih dan Kevangan. Jakarta: Raja Grafindo Persada

Kasmir, 1999, Bank dan Lembaga Kevangan Lainnya, Edisi Baru, PT.RajaGrafindo Persada, Jakarta Lestari, Elly. 2011. Pengujian Reaksi Pasar Terhadap Perusahaan yang Melakukan Stock Splits Berdasarkan Rasio Split di Bursa Efek Indonesia. Tesis. Universitas Airlangga.

Mannan, M. Abdul. 2007. Obligasi Syariah. (Online) http://badilag.net diakses 5 Desember 2010

Manurung, Adler Haymans \& Ira, Cahyanti. 2002. Pengaruh Peristiwa Politik (Pengumuman Hasil Pemilu Legislatif, Pengumuman Susunan Kabinet, Reshulffle Kabinet) terhadap Sektor-sektor Industri di Bursa Efek Jakarta.

Meidawati, Neni dan Mahendra Harimawan. 2004. The Impact of Bank Restructuring Announcements on The Banking 
Stock Prices: The Cases of Indonesia's Bonds on May 28, 1999. Gajah Mada International Journal of Business. No I : 119-139

Mujahid, dan Tettet Fitrijanti. 2010. Pengaruh Penerbitan Obligasi Syariah (Sukûk) Perusahaan Terhadap Reaksi Pasar. SNA XIII. Universitas Jenderal Soedirman Purwokerto.

Nasution, Mustafa Edwin \& Huda, Nurul. 2008. Investasi pada pasar Modal Syariah. Jakarta: Kencana

Nursiam dan Puteranto, Lastiyono Doso. 2004. Analisis Efisiensi PasarModal Indonesia Periode 1998-2000 (Studi pada PT.Bursa Efek Jakarta). Jurnal Akuntansi dan Keuangan.

Nusantara, Agung. 2004. Pasar Modal Islami Antrara Harapan dan Kenyataan. Fokus Ekononi. Agustus, Vol. 3, No. 2

Pratiwi, Widiati. 2012. Pengaruh Informasi Penerapan Good Corporate Governance Terhadap Kenaikan Harga Saham Pada PT Adhi Karya (Persero) Tbk. Skripsi. Universitas Pendidikan Indonesia.

Ryandono, Muhamad Nafik H. 2009. Bursa

Efek dan Investasi Syariah. Jakarta: Serambi.

Siamat, Dahlan. 2005. Manajemen Lembaga Keuangan. Edisi Kelima. Lembaga Penerbit Fakultas Ekonomi Universitas Indonesia.

Sudana, I Made. 2009. Manajemen Keuangan Teori dan Praktik.
Surabaya: Airlangga University

Press.

Sudarsono, Heri. 2008. Bank dan Lembaga Keuangan Syariah. Yogyakarta: Ekonisia

Sugiyono. 2009. Metode Penelitian Kuantitatif Kualitatif dan R\&D. Bandung:Alfabeta

Sukmaningrum, Puji Sucia. 2012. Reaksi Pasar Terhadap Pengumuman Penerbitan Obligasi Syariah di Bursa Efek Indonesia. Program Sarjana Universitas Airlangga

Supranto J. 2009. Statistik Teori dan Aplikasi. Edisi Ketujuh. Jakarta: Erlangga.

Suryabrata, Sumadi. 2009. Metodologi Penelitian. Jakarta: Raja Grafindo Persada.

Suryomurti, Wiku. 2011. Supercerdas Investasi Syariah, Jakarta: Qultum Media

Sutedi, Adrian. 2011 . Pasar Modal Syariah. Jakarta: Sinar Grafika

Tandelilin, Eduardus. 2001. Analisis Investasi Dan Manajemen Portofolio. Yogyakarta: BPFE Yogyakarta

Tariq, Ali Arsalan. 2004. Managing Financial Risk of Sukûk Structures. Disertasi, tidak diterbitkan. UK. Longboroungh University.

Touriq, Muhammad. 2011. Arah Kebijakan Pengembangan Pasar Modal Syariah. Iqtishodia Jurnal Ekonomi Islam Republika. Hal.23 Tahun 2011

Wahid, Nazaruddin Abdul. 2010. Sukûk: Memahami dan Membedah 
JESTT Vol. 1 No. 5 Mei 2014

Obligasi pada Perbankan Syariah. www.finance.yahoo.com

Yogyakarta: Ar-Ruzz Media.

www.idx.co.id

wWw.adiwarmankarim.com

www.standartandpoors.com

www.duniainvestasi.com 